УДК 346.1:347.736

DOI https://doi.org/10.32849/2663-5313/2020.4.12

Антон Гушилик,

аспірант кафедри юридичних дисчиплін

Донецького юридичного інституту Міністерства внутрішніх справ Украйни

\title{
ПРАВОВЕ СТАНОВИЩЕ БОРЖНИКА У СПРАВІ ПРО БАНКРУТСТВО НА СТАДІЇ САНАЦІЇ
}

Стаття присвячена дослідженню правового становища неплатоспроможного боржника у справі про банкрутство на стадії санації. Автором наголошено, що натепер доводиться констатувати низьку ефективність відновлювальних процедур у національній системі банкрутства. Аналіз законодавства про банкрутство дозволяє виділити три проиедури, в яких закладено відновлювальний механізм - розпорядження майном боржника, саначія та мирова угода. Кожна з иих прочедур має своєю иіллю відновлення платоспроможності боржника. Відрізняються вони одна від одної в основному ступенем втручання в управління боржником. Так, якщо у разі укладення мирової угоди керівництво боржника зберігається у повному складі, то під час прочедури саначії, за загальним правилом, керуючий санацією замінює керівника боржника.

Метою статті є теоретичне осмислення особливостей правового становища боржника у справі про банкрутство на стадії санації.

Автором аргументовано, що процедура санації існує у двох проявах - досудовій санаиії та санаиії, яка триває під час провадження у справі про банкрутство. Прочедура санаиії є найбільш оптимальною, оскільки дозволяє задовольнити вимоги кредиторів та відновити платоспроможність боржника. Крім цвого, не варто забувати про соціальний ефекти санації, а саме: збереження містоутворюючих підприємств та робочих місиь, сплату податків тощо.

Внаслідок дослідження правового статусу боржика у проиедурі санаиї автор доходить висновку, що ия процедура є найбільш сприятливою для боржника $і \epsilon$ «парасолькою», яка захищає його від кредиторів. У прочедурі санаиї господарська діяльність боржника продовжується, однак керівниитво боржником переходить до нейтральної особи - арбітражного керуючого. Керівник боржника у разі введення проиедури санащії підлягає звільненню, що відбувається на підставі ухвали господарського суду, в якій, серед іншого, вказується на припинення повноважень керівника боржника. У даному випадку положення законодавства про банкрутство, як спеціального законодавства, мають пріоритет над нормами трудового права. Фактично керуючий саначією стає керівником боржника, при цьому корпоративні права учасників боржника зберігаються, але їхня правомочність є обмеженою.

Ключові слова: банкрутство, неплатоспроможність, санація, боржник, Кодекс України з процедур банкрутства.

Постановка проблеми. Право неспроможності (банкрутства) має на меті не лише задоволення вимог кредиторів неплатоспроможного боржника, але і відновлення платоспроможності останнього. Для цього у законодавстві про банкрутство передбачено широкий спектр засобів, спрямованих на відновлення платоспроможності боржника. Однак, на жаль, доводиться констатувати низьку ефективність відновлювальних процедур у національній системі банкрутства. Особливої актуальності проблеми неплатоспроможності та банкрутства набули у зв'язку із набуттям чинності Кодексом України з процедур банкрутства (далі - КУзПБ), у зв'язку з чим актуальним залишається дослідження особливостей правового становища неплатоспроможного боржника на стадії санації.

Аналіз останніх досліджень i публікацій. Серед вітчизняних науковців, які активно досліджують проблеми неплатоспроможності та банкрутства, слід відзначити: О. А. Беляневич, О. М. Бірюкова, А. А. Бутирського, I. А. Бутирську, I. О. Вечірка, В. В. Джуня, Ю. В. Кабенок, Б. М. Полякова, О. П. Подцерковного, П. Д. Пригузу та інших. У працях згаданих вчених детально досліджуються теоретичні та практичні проблеми, пов'язані з банкрутством. Разом із тим актуальним залишається теоретичне осмислення та аналіз особливостей правового становища неплатоспроможного боржника на стадії санації. 
| Метою статті $\epsilon$ теоретичне осмислення особливостей правового становища боржника у справі про банкрутство на ста॥ дії санації.

Виклад основного матеріалу. Термін «санація» походить від латинського слова Sanatio, що означає оздоровлення, лікування. У процедурі банкрутства термін «санація» застосовується у прямому значенні - оздоровлення боржника. Слід зазначити, що перший закон, який регулював відносини неспроможності, називався Закон України «Про банкрутство», і у даному випадку назва цілком відповідала змісту, тому що згаданий закон мав на меті лише одне - ліквідацію боржника у найкоротший час. Практичне застосування зазначеного закону виявило значні недоліки у процедурі банкрутства, оскільки цей закон був виключно «санітаром економіки», звільняючи останню від непрацюючих або працюючих неефективно підприємств. Що стосується санації, то даний інститут був окреслений схематично і передбачав, що арбітражний суд може винести ухвалу про проведення санації боржника якщо надійшли пропозиції від бажаючих задовольнити вимоги кредиторів до боржника і виконати його зобов'язання перед бюджетом, за умови згоди зборів (комітету) кредиторів зі строками виконання цих зобов'язань і на переведення боргу. Право вибору умов проведення санації шляхом реорганізації, приватизації залишається за боржником у разі, якщо він сам звернувся до арбітражного суду із заявою про визнання його банкрутом. Отже, набір інструментів санації був дуже вузьким, що спричинило його низку ефективність.

Такий стан речей негативно впливав на економіку всієї держави, що зумовило прийняття у 1999 р. нового банкрутського закону, який називався «Про відновлення платоспроможності боржника або визнання його банкрутом». Новий закон передбачив запровадження інституту санації на нових засадах. Так, під санацією розумілась система заходів, що здійснюються під час провадження у справі про банкрутство 3 метою запобігання визнанню боржника банкрутом та його ліквідації, спрямована на оздоровлення фінансово-господарського становища боржника, а також задоволення в повному обсязі або частково вимог кредиторів шляхом кредитування, реструктуризації підприємства, боргів і капіталу та (або) зміну організаційно-правової та виробничої структури боржника.

Також було запроваджено досудову санацію, яка визначалась як система заходів щодо відновлення платоспроможності борж- ника, які може здійснювати власник майна (орган, уповноважений управляти майном) боржника, інвестор 3 метою запобігання банкрутству боржника шляхом реорганізаційних, організаційно-господарських, управлінських, інвестиційних, технічних, фінансово-економічних, правових заходів відповідно до законодавства до початку порушення провадження у справі про банкрутство.

Таким чином, процедура санації існує у двох проявах - досудовій санації та санації, яка триває під час провадження у справі про банкрутство.

По своїй суті процедура санації є реабілітаційною процедурою у справі про банкрутство. Під самим поняттям «реабілітація» прийнято розуміти відновлення у правах. Реабілітація у процедурі банкрутства - це також відновлення прав божника. Однак із відновленням прав боржника, як наслідок, відновлюються і права кредиторів, що є особливістю процедури санації. Як відомо, підставою для відкриття провадження у справі про банкрутство є не лише безвідповідальне ставлення боржника до своїх зобов'язань. Фактори виникнення неплатоспроможності можуть бути найрізноманітнішими, але загалом їх можна поділити на дві групи: зовнішні та внутрішні. До перших належать: кон'юнктура на ринку, доступність і дешевизна кредитів, курс валют, рівень інфляції тощо. Натомість внутрішні фактори зумовлені невдалою діяльністю засновників (учасників) боржника та його менеджменту [1, c. 89].

У будь-якому разі фінансові труднощі боржника можуть бути тимчасовими, а тому ліквідація боржника $є$ крайнім заходом, i, перш ніж вдаватись до такої процедури, необхідно вжити всіх заходів для відновлення платоспроможності боржника та його конкурентоспроможності на ринку. Процедура санації $є$ найбільш оптимальною, оскільки дозволяє задовольнити вимоги кредиторів та відновити платоспроможність боржника. Крім цього, не варто забувати про соціальні ефекти санації, а саме: збереження містоутворюючих підприємств та робочих місць, сплату податків тощо.

Своєчасне виявлення стану неплатоспроможності боржника та його всебічний аналіз дозволяють провести систему заходів, що здійснюються під час провадження у справі про банкрутство з метою запобігання визнанню боржника банкрутом та його ліквідації, яка спрямована на оздоровлення фінансово-господарського становища боржника, а також задоволення в повному обсязі або частково вимог кредиторів через реструктуризацію підприємства, боргів і активів та/або 
зміну організаційно-правової та виробничої структури боржника [2, с. 114].

Важливим питанням є мета застосування тієї чи іншої процедури банкрутства. Так, в узагальненому вигляді у процедурах банкрутства можна виділити дві основні цілі відновлення платоспроможності боржника та захист інтересів його кредиторів. Причому щодо кредиторів Т. Адамова та Т. Корень абсолютно правильно зауважують, що очевидно, що ціллю кредитора є не припинення діяльності боржника та виключення його з Єдиного державного реєстру юридичних осіб та приватних підприємців (так називається реєстр у Республіці Білорусь - А.Г.), а отримання грошових коштів за зобов'язаннями боржника [3, с. 22]. Для правовідносин неспроможності характерною є висока конфліктогенність між учасниками провадження у справі про банкрутство, зумовлена бажанням кожного суб'єкта (як боржника, так і кожного з кредиторів) максимально захистити свої інтереси [4, с. 106]

$\mathrm{y}$ науці прийнято виділяти три механізми, що застосовуються у процедурі банкрутства: попереджувальний, відновлювальний та ліквідаційний [5, с. 4-9]. Під час процедури санації використовується відновлювальний механізм. На думку А. Ф. Малікова, механізм банкрутства - це сукупність заходів, передбачених законодавством про банкрутство, за допомогою яких залежно від ситуації здійснюється одна із задач процесу банкрутства: або попередження банкрутства боржника, або його відновлення, або ліквідація. Відповідно, відновлювальний механізм банкрутства - це сукупність заходів, передбачених законодавством про банкрутство, завданням яких є відновлення платоспроможності юридичної особи - боржника [6, с. 57]. Ю. В. Кабенок також наголошує, що безпосереднє відновлення платоспроможності боржника в межах процедури банкрутства фактично відбувається в одній із реабілітаційних судових процедур - процедурі санації [7, с. 119].

Аналіз законодавства про банкрутство дозволяє виділити три процедури, в яких закладено відновлювальний механізм, розпорядження майном боржника, санація та мирова угода. Кожна із цих процедур має своєю ціллю відновлення платоспроможності боржника. Відрізняються вони одна від одної в основному ступенем втручання в управління боржником. Так, якщо у разі укладення мирової угоди керівництво боржника зберігається у повному складі, то під час процедури санації, за загальним правилом, керуючий санацією замінює керівника боржника.
Остання редакція Закону України «Про відновлення платоспроможності боржника або визнання його банкрутом» містила чимало проблемних питань, які виникають під час реалізації майна банкрута. На жаль, велика кількість цих проблем «перекочувала» й у новий Кодекс України 3 процедур банкрутства [8, с. 47].

Як слушно відзначає І. Іванова, санація $€$ основною формою фінансового оздоровлення боржника. Процедура санації вводиться тільки в тому разі, якщо підприємство має реальну можливість відновити свою платоспроможність [9, с. 47]. Заходами фінансового оздоровлення можуть бути: реструктуризація підприємства, участь інвестора, продаж частини майна тощо [10, с. 74-75]. Використання санації $є$ доцільним щодо тих підприємств, які тимчасово потрапили у скрутне становище, а вартість активів такого підприємства значно перевищує кредиторську заборгованість [11, с. 125].

Якщо говорити про правовий статус боржника у процедурі санації, то ця процедура $€$ найбільш сприятливою для нього і $є$ «парасолькою», яка захищає його від кредиторів. Дане твердження зумовлене тим, що боржник у процедурі санації продовжує здійснювати власну виробничу діяльність. Крім того, позитивним моментом для боржника є те, що арешт на майно боржника та інші обмеження дій боржника щодо розпорядження його майном можуть бути накладені лише в межах процедури санації, за умови що вони не перешкоджають виконанню плану санації та не суперечать інтересам конкурсних кредиторів. Не допускається арешт грошових коштів, що перебувають на банківських рахунках умовного зберігання (ескроу), відкритих боржником у встановленому законодавством порядку. Також господарський суд за заявою керуючого санацією може знімати арешт з майна боржника чи інші обмеження щодо розпорядження його майном, якщо такі арешт чи обмеження перешкоджають виконанню плану санації, господарській діяльності боржника та відновленню його платоспроможності (ч. 4 ст. 50 КУзПБ).

До негативних наслідків для боржника слід віднести таке:

- члени виконавчого органу (керівник) боржника звільняються з посади у порядку, визначеному законодавством;

- управління боржником переходить до керуючого санацією;

- зупиняються повноваження органів управління боржника - юридичної особи щодо управління та розпорядження майном боржника, повноваження органів управління передаються керуючому санацією, крім повноважень, передбачених планом санації. 
Зосередження всіх повноважень (і керівника, i органів управління боржника) в руках однієї особи - керуючого санацією - $є$ необхідним елементом процедури санації, оскільки дозволяє сконцентрувати прийняття всіх важливих для боржника рішень в руках однієї професійної особи. А. Г. Бобкова та З. Ф. Татькова відзначають, що, на жаль, у Законі про банкрутство не зазначено про долю керівника боржника, якщо він не став керуючим санацією. Можна припустити, продовжують науковці, що він продовжує перебувати у трудових відносинах і не підлягає звільненню, оскільки в законодавстві немає відповідної підстави [12, c. 109].

На нашу думку, керівник боржника у разі введення процедури санації підлягає звільненню, що відбувається на підставі ухвали господарського суду, в якій, серед іншого, вказується на припинення повноважень керівника боржника. У даному випадку положення законодавства про банкрутство, як спеціального законодавства, мають пріоритет над нормами трудового права.

Таким чином, у процедурі санації господарська діяльність боржника продовжується, однак керівництво боржником переходить до нейтральної особи - арбітражного керуючого. Фактично керуючий санацією стає керівником боржника, при цьому корпоративні права учасників боржника зберігаються, але їхня правомочність є обмеженою.

Як зазначено вище, управління боржником здійснює керуючий санацією, але він не може за обсягом повноважень прирівнюватись до керівника підприємства у класичному розумінні. Керуючий санацією повинен діяти на виконання плану санації, який затверджується кредиторами, а одним із повноважень згаданої особи є розпорядження майном боржника відповідно до плану санації та з урахуванням обмежень, встановлених законодавством.

T. Чубар вказує на те, що план санації може містити умови про: виконання зобов'язань боржника третіми особами; задоволення вимог кредиторів іншим способом, що не суперечить законодавству; відшкодування коштів, витрачених на проведення зборів акціонерів та (або) засідань органів управління боржника відповідно до Закону про банкрутство [13, с. 198]. Білоруський вчений О. Смольський відзначає, що структура та зміст плану санації повинні бути аналогічними структурі та змісту бізнесплану розвитку організації, але враховувати необхідність змін, спрямованих на суттєве підвищення ефективності роботи за всіма напрямами [14, с. 49]. I. А. Бутирська також звертає увагу на те, що основним і найважливішим документом, на основі якого здійснюється процес фінансового оздоровлення господарської діяльності боржника, є план санації. Від правильності його складання залежить успіх реалізації всієї процедури санації [15, с. 92-93].

Аналіз КУзПБ дозволяе виділити обов'язкові умови плану санації, до яких слід віднести: розмір вимог кожного класу кредиторів; заходи щодо відновлення платоспроможності боржника; строк відновлення платоспроможності боржника; забезпечення погашення заборгованості боржника з виплати заробітної плати.

\section{Висновки}

Підсумовуючи викладене, доходимо таких висновків. Процедура санації існує у двох проявах - досудовій санації та санації, яка триває під час провадження у справі про банкрутство. Процедура санації є найбільш оптимальною, оскільки дозволяє задовольнити вимоги кредиторів та відновити платоспроможність боржника. Крім цього, не варто забувати про соціальні ефекти санації, a саме: збереження містоутворюючих підприємств та робочих місць, сплату податків тощо. Якщо говорити про правовий статус боржника у процедурі санації, то ця процедура $є$ найбільш сприятливою для нього і $€$ «парасолькою», яка захищає його від кредиторів. У процедурі санації господарська діяльність боржника продовжується, однак керівництво боржником переходить до нейтральної особи - арбітражного керуючого. Фактично керуючий санацією стає керівником боржника, при цьому корпоративні права учасників боржника зберігаються, але їхня правомочність є обмеженою.

\section{Список використаних джерел:}

1. Бутирський А. Концепція удосконалення законодавства про неспроможність. Право України. 2018. № 6. С. 86-97.

2. Мелех Л. В., Круць К. І. Санація боржника як судова процедура у справі про банкрутство. Вісник Національного університету «Львівська політехніка». Юридичні науки. 2015. № 827. C. $110-114$.

3. Адамова Т., Корень Т. Подача заявления кредитора о банкротстве должника как способ защиты нарушенного права. Судебный вестник плюс: экономическое правосудие. 2017. № 6. C. 21-24.

4. Бутирська I. А. Функції господарського суду у справі про банкрутство. Вісник господарського судочинства. 2015. № 4. С. 106-111.

5. Карелина С. А. Правовые проблемы предупреждения несостоятельности (банкротства). 
Предпринимательское право. Приложение «Бизнес и право в России и за рубежом». 2011. № 3. С. 4-9.

6. Маликов А. Ф. Правовое регулирование реабилитационных процедур несостоятельности (банкротства) : дисс. ... канд. юрид. наук: 12.00.03. Москва, 2017. 220 с.

7. Кабенок, Ю. В. Правове регулювання арбітражного управління в процедурі банкрутства в Україні : дис. ... канд. юрид. наук : 12.00.04. Київ, 2018. 242 c.

8. Бутирський А. Проблемні питання реалізації майна банкрута у ліквідаційній процедурі. Економіка та право. 2019. № 2. С. 78-83.

9. Иванова И. Финансовое оздоровление и санация через призму судебной практики. Судебньй вестник плюс: экономическое правосуวue. 2017. № 2. C. 44-51.

10. Поляков Б. M. Науково-практичний коментар Закону України «Про відновлення платоспроможності боржника або визнання його банкрутом від 14 травня 1992 р. № 2343-XII в редакції Закону України від 22 грудня 2011 р. № 4212-VI. Саначія та банкрутство. 2016. № 3-4. С. 71-88.
11. Бутирський А. А. Правове регулювання заходів щодо відновлення платоспроможності боржника : дис. ... канд. юрид. наук : 12.00.04. Київ, 2007. $200 \mathrm{c}$.

12. Бобкова А. Г., Татькова 3. Ф. Правове регулювання відносин у процедурі банкрутства : навчальний посібник. Київ : Центр навчальної літератури, 2006. 152 с.

13. Чубар Т. М. Особливості практичного застосування заліку зустрічних однорідних вимог у процедурі санації. Сучасні виклики та актуальні проблеми судової реформи в Україні : матеріали II Міжнар. наук.-практ. конф. (Чернівці, 18-19 жовтня 2018 р.) / редкол. : О. В. Щербанюк (голова) А. С. Цибуляк-Кустевич (відпов. секр.) та ін. Чернівці, 2018. С. 197-200.

14. Смольский А. Особенности санации сельскохозяйственных организаций. Судебный вестник плюс: экономическое правосудие. 2017. № 10. C. 46-52.

15. Бутирська I. А. Учасники провадження у справі про банкрутство: дис. ... канд. юрид. наук: 12.00.04. Київ, 2017. 204 с.

The article is devoted to the investigation of the legal status of an insolvent debtor in the bankruptcy case at the stage of rehabilitation. The author emphasized that today it is necessary to ascertain the low efficiency of recovery procedures in the national bankruptcy system. Bankruptcy law analysis identifies three procedures that provide for a recovery mechanism - the disposal of the debtor's property, rehabilitation and amicable settlement. Each of these procedures is intended to restore the solvency of the debtor. They differ from each other mainly in the degree of intervention in the management of the debtor. Thus, if the settlement of the debtor's leadership is maintained in its entirety at the conclusion of the amicable settlement, then, as a general rule, the debtor's manager replaces the debtor's manager during the reorganization procedure.

The purpose of the article is to give a theoretical understanding of the peculiarities of the debtor's legal position in the bankruptcy case at the stage of rehabilitation.

The author argues that the procedure for rehabilitation exists in two manifestations - pre-trial rehabilitation and rehabilitation, which continues during the bankruptcy proceedings. The reorganization procedure is the most optimal because it allows to satisfy the requirements of creditors and restore the solvency of the debtor. In addition, you should not forget about the social effects of redevelopment, such as the preservation of town-forming enterprises and jobs, taxes, and more.

As a result of the study of the legal status of the debtor in the rehabilitation procedure, the author concludes that this procedure is the most favorable for the debtor and is an "umbrella" that protects him from the creditors. The debtor's economic activity continues in the course of the reorganization process, but the management of the debtor goes to a neutral person - the arbitrator. The debtor's manager in case of introduction of the procedure of reorganization is subject to release, which occurs on the basis of the decision of the economic court, in which, among other things, it indicates the termination of the authority of the debtor's head. In this case, the provisions of bankruptcy law, as special legislation, take precedence over labor law. In fact, the resolution manager becomes the debtor's manager, while the corporate rights of the debtor's participants are retained, but their competence is limited.

Key words: bankruptcy, insolvency, rehabilitation, debtor, Bankruptcy Code of Ukraine. 